\title{
Effects of Buchholzia coriacea Seed on Nutrient Utilization and Serum Biochemical Parameters in Alloxan-Induced Diabetic Rat
}

\author{
Nuria C. Amaechi ${ }^{1}$, Philippa C. Ojimelukwe ${ }^{2}$ and Samuel O. Onoja ${ }^{3,{ }^{*}}$ \\ ${ }^{1}$ Department of Food Science and Technology, Abia State University, Umuahia Campus, Abia State Nigeria \\ ${ }^{2}$ Department of Food Science and Technology, Michael Okpara University of Agriculture, Umudike PMB \\ 7267, Umuahia, Abia State Nigeria \\ ${ }^{3}$ Department of Veterinary Physiology and Pharmacology, Michael Okpara University of Agriculture Umudike, \\ PMB 7267, Umuahia, Abia State Nigeria
}

\begin{abstract}
The effects of Buchholzia coriacea seed on the nutrient utilization and biochemical parameters in alloxaninduced diabetic rat were evaluated. Buchholzia coriacea (BC) seed was washed, sliced, dried, pulverized and mixed with standard ration at $2.5 \%, 5 \%, 10 \%$ and $20 \%$. The proximate nutrient composition of the standard and prepared rations was determined. The Buchholzia coriacea incorporated rations and standard ration were fed to alloxan-induced diabetic rats for 70 consecutive days. The nutrient utilization and biochemical parameters as well as the histopathology of pancreas of the treated rats were evaluated. The Buchholzia coriacea at $2.5 \%$ inclusion rate significantly $(p<0.05)$ improved the nutrient utilization and biochemical parameters that were compromised in diabetic rats fed with standard ration alone. The $B$. coriacea also reversed the pancreatic islet damage induced by alloxan. Buchholzia coriacea have potent antidiabetic and hypolipidemic activities and should not be incorporation in excess of $5 \%$ in the diet.
\end{abstract}

Keywords: Apparent digestibility, biological value, hypolipidemia, gas chromatography, glycosylated hemoglobin.

\section{INTRODUCTION}

Buchholzia coriacea Engl (wonderful kola) is a member of the family Capparidaceae and is found in Guinea, Ghana, Liberia, Cameroon, Gabon and Southern Part of Nigeria [1]. It is an evergreen tree (10 - 20 metre high) with smooth, blackish-brown stem, large glossy pinnate leaf and conspicuous white or yellow flower at the terminal of the branches. The seed has sharp pungent taste and traditionally used as a spice and medicine [2]. The seed is used as aphrodisiac in Cameroon, childbirth enhancer in Ivory Coast and antidiabetic agent in Nigerian ethnomedical practice. The antiulcer, analgesic, antidiabetic, anthelminthic, antibacterial, anti-inflammaory and antioxidant activities of $B$. coriacea have been reported [3-9]. There is paucity of information on the effects of Buchholzia coriacea on nutrient utilization and clinical biochemical parameters in alloxan-induced diabetes mellitus. This study was designed to investigate the effects of Buchholzia coriacea seed on nutrient utilization and clinical biochemical parameters in alloxan-induced diabetic rat.

\footnotetext{
${ }^{*}$ Address correspondence to this author at the Department of Veterinary Physiology and Pharmacology, College of Veterinary Medicine, Michael Okpara University of Agriculture, PMB 7267, Umudike, Abia State Nigeria; Tel: +2348030613032; E-mail: samonreal@yahoo.com, samuelonoja19@yahoo.com
}

\section{MATERIALS AND METHODS}

\section{Plant Collection and Extract Preparation}

Fresh Buchholzia coriacea seeds were procured from Abakpa Market Abakaliki, Ebonyi state, Nigeria and authenticated by a botanist. It was peeled, washed, and cut into smaller pieces before air drying under a shade for 10 days at environmental temperature $\left(25 \pm 2{ }^{\circ} \mathrm{C}\right)$. The seeds were pulverized and stored in air tight container before usage. The pulverized seed was extracted with soxhlet apparatus maintained at $40{ }^{\circ} \mathrm{C}$ using acetone for $24 \mathrm{~h}$. The extract was concentrated with rotary evaporator at $40{ }^{\circ} \mathrm{C}$.

\section{Gas Chromatography/Mass Spectrometry Analysis}

The bioactive compounds in acetone extracts of Buchholzia coriacea seed was analyzed using gas chromatography/mass spectrometry (QP 2010 Plus Shimadzu, Japan) equipped with a flame ionization detector (FID). Helium was used as carrier gas and at a flow rate of $3.0 \mathrm{~mL} / \mathrm{min}$. The column temperature was programmed from 70 to $280^{\circ} \mathrm{C}$ at the rate of $5^{\circ} \mathrm{C} / \mathrm{min}$. Injector and detector temperatures were set at 250 and $260^{\circ} \mathrm{C}$, respectively. All quantifications were carried out using a built-in data-handling program provided by the manufacturer of the GC (Perkin Elmer, Norwalk, CT, USA). Interpretation of mass spectrum from gas chromatography-mass spectrum was conducted using 
the database National Institute Standard and Technology (NIST) version 2.0, 2009 library.

\section{Formulation of Experimental Diet}

The diets were formulated as described by Amaechi et al. [10]. Briefly, standard diet containing 83\% corn starch, $10 \%$ casein, $2 \%$ vegetable oil, $3 \%$ rice bran and $2 \%$ vitamin and mineral mix was prepared. The dried pulverized Buchholzia coriacea (BC) seed was incorporated at different concentrations of $2.5 \%, 50 \%$, $10 \%$ and $20 \%$ to standard ration.

\section{Experimental Animals}

Weanling albino Wistar rats (22-26 days old) of both sexes with average initial body weight of $40 \pm 2$ gram were used for the experiments. The rats were obtained from a reputable source and housed in stainless steel metabolism cages maintained at an ambient temperature of $28 \pm 2{ }^{\circ} \mathrm{C}$ and natural light-dark cycle. All the experimental animals were acclimatized for 14 days on the standard diet. The rats were maintained in accordance with the recommendation in the guide for the care and use of laboratory animals [11]. The experimental protocol was approved by the Institutional Ethics Committee.

\section{Proximate Analysis of Diet Samples}

Proximate composition of the various diet samples were analyzed by the methods described by James [12].

\section{Induction of Diabetes}

Diabetes was induced by intraperitoneal injection of alloxan $(160 \mathrm{mg} / \mathrm{kg})$ to overnight $(16 \mathrm{~h})$ fasted rats with free access to water. After $72 \mathrm{~h}$, fasting blood glucose levels of the rats were determined with a glucometer (Accu-check active, Germany).

\section{Experimental Design}

The method described by Pellet and Young [13] was adopted. Eight (8) normoglycemic and 40 diabetic rats were used for the experiment. The normoglycemic rats were assigned group I and diabetic rats were randomly assigned to 5 groups (II - VI) of 8 rats each. The rats were individually housed in metabolic cage. Groups I and II were fed with standard feed while groups II - VI were fed with feed containing 2.5, 5, 10 and $20 \%$ BC seed, respectively. The rats were fed ad libitum for 70 consecutive days. The daily feed intake was recorded, while the body weight was recorded at weekly interval. The daily fecal output was recorded, collected and air dried while the daily urine output was recorded, pooled and stored by addition of $1 \mathrm{ml}$ of 0.1 $\mathrm{N} \mathrm{HCl}$ in brown bottle nitrogen analysis. After the $70^{\text {th }}$ day of feeding, the rats were fasted for $16 \mathrm{~h}$ and blood samples were collected through ocular puncture into EDTA and plain bottle for whole blood and serum preparation respectively. Thereafter, the rats were sacrificed by cervical dislocation, immediately laparotomised and pancreas were excised and preserved in $10 \%$ formalin solution for histopathological examination.

\section{Evaluation of Nutrient utilization}

Nitrogen content of both urine and feacal samples was analyzed using the kjeldahl method as described by James [12]. Protein efficiency ratio (PER), feed efficiency ratio (FER), apparent digestibility (AD), true digestibility (TD), biological value (BV) and net protein utilization (NPU) were calculated.

\section{Serum Biochemical Analysis}

Fasting blood glucose (FBG) was determined using a glucometer (Accu- check, Germany). Glycosylated hemoglobin $(\mathrm{HbA} 1 \mathrm{c})$ was analyzed by the method of Trivelli et al. [14], using a glycohemoglobin test kit (Teco Diagnostics, USA). The serum total cholesterol (TC), triglycerides (TG) high density lipoprotein cholesterol (HDL-C) were analysed using a commercial available diagnostic test kit (Randox Laboratory, UK). Serum low density lipoprotein cholesterol (LDL-C) was calculated using Fridewald equation [15]:

LDL-C $(\mathrm{mg} / \mathrm{dl})=$ Total cholesterol $-($ Triglycerides $/ 5)-$ HDL-C.

\section{Histopathology}

The Pancreas of the rats were excised and fixed in $10 \%$ formol saline for $24 \mathrm{~h}$. They were washed in ascending grades of ethanol, cleared with xylene, embedded in paraffin wax, sectioned with a microtome, and stained with hematoxylin and eosin ( $\mathrm{H}$ and $\mathrm{E}$ ) and mounted on Canada balsam (Sigma-Aldrich, St. Louis, MO) [16]. All the sections were examined under a light microscope at $\times 400$ magnification. Photomicrographs of lesions were taken with an Olympus photo microscope (Olympus Scientific Equipment, Ashburn, VA) for observations of the histopathological lesions.

\section{Statistical Analysis}

One way analysis of variance (ANOVA) followed by Duncan's Post hoc test was used to separate the 
means. Data obtained were expressed as mean \pm standard deviation and differences in means were considered to be significant at $p<0.05$. The statistical software used was SPSS version 20.

\section{RESULT}

\section{Bioactive Compounds Identified in the Acetone Extract of Buchholzia coriacea Seeds}

The GC/MS analysis of the acetone extract of $B$. coriacea showed the presence of nine compounds. Their retention time, peak area, molecular weight and formulae are presented in Table 1. 9-Octadecanoic acid $(Z)$ (Oleic acid) and 9,12-Octadecadienoyl chloride $(Z, Z)$ (Linoleic acid chloride) were the most abundant with the peak areas of $39.22 \%$ and $39.35 \%$ respectively.

\section{Proximate Composition of Standard Ration and Rations Containing $B$. coriacea at Varied Concentrations}

The incorporation of $B$. coriacea caused concentration-dependent $(p<0.05)$ increase in the proximate moisture, fat, ash, crude fiber and protein content of the treated rations when compared with the standard ration. The carbohydrate content of the $B$. coriacea-treated rations decreased ( $p<0.05)$ in concentration dependent manner when compared with the standard ration (Table 2 ).

\section{Effect of $B$. coriacea on the Nutrient Utilization in Diabetic Rats}

The body mass gain (BMG), protein efficiency ratio (PER), feed efficiency ratio (FER), urinary nitrogen (UN), endogenous urinary nitrogen (EUF), endogenous fecal nitrogen (EFN), percentage nitrogen retention

Table 1: Bioactive Compounds Identified in the Acetone Extract of Buchholzia coriacea Seeds

\begin{tabular}{|c|c|c|c|c|c|}
\hline $\begin{array}{l}\text { Peak } \\
\text { No }\end{array}$ & $\begin{array}{l}\text { Retention } \\
\text { Time (Minutes) }\end{array}$ & Identity of Compound & Peak Area (\%) & $\begin{array}{l}\text { Molecular } \\
\text { Weight }\end{array}$ & $\begin{array}{l}\text { Molecular } \\
\text { Formular }\end{array}$ \\
\hline 1 & 3.64 & Trimethylsilylmethanol & 1.58 & 104 & $\mathrm{C}_{4} \mathrm{H}_{12} \mathrm{OSi}$ \\
\hline 2 & 8.63 & $\begin{array}{l}\text { 2,6-octadien-1-ol-3,7-dimethyl (E) trans geraniol } \\
\text { (Lemonol or Nerol) }\end{array}$ & 0.40 & 154 & $\mathrm{C}_{10} \mathrm{H}_{18} \mathrm{O}$ \\
\hline 3 & 8.88 & 2,6-Octadienal-3,7-dimethyl-(E) $\alpha$ citral & 0.89 & 152 & $\mathrm{C}_{10} \mathrm{H}_{16} \mathrm{O}_{2}$ \\
\hline 4 & 14.05 & a-(4methyl-3-pentenyl) oxirane methanol & 1.58 & 170 & $\mathrm{C}_{10} \mathrm{H}_{18} \mathrm{O}_{2}$ \\
\hline 5 & 20.90 & $\begin{array}{l}\text { 9-Octadecenoic acid, methyl ester } \\
\text { (Oleic acid methyl ester) }\end{array}$ & 1.14 & 296 & $\mathrm{C}_{19} \mathrm{H}_{36} \mathrm{O}_{2}$ \\
\hline 6 & 22.12 & $\begin{array}{c}\text { 9-Octadecanoic acid (Z) } \\
\text { (Oleic acid) }\end{array}$ & 39.22 & 282 & $\mathrm{C}_{18} \mathrm{H}_{34} \mathrm{O}_{2}$ \\
\hline 7 & 23.32 & Hexadecanoic acid, 2-hydroxy-1, 3-propanediyl ester & 8.86 & 568 & $\mathrm{C}_{35} \mathrm{H}_{68} \mathrm{O}_{5}$ \\
\hline 8 & 24.88 & $\begin{array}{c}\text { 9,12-Octadecadienoyl chloride (Z,Z) } \\
\text { (Linoleic acid chloride) }\end{array}$ & 39.35 & 298 & $\mathrm{C}_{18} \mathrm{H}_{31} \mathrm{ClO}$ \\
\hline 9 & 25.03 & Octadecanoic acid, 2-hydroxy-1, 3-propanediyl ester & 7.60 & 624 & $\mathrm{C}_{39} \mathrm{H}_{76} \mathrm{O}_{5}$ \\
\hline
\end{tabular}

Table 2: Proximate Composition of Standard Ration and Rations Containing B. coriacea at Varied Concentrations

\begin{tabular}{|c|c|c|c|c|c|}
\hline Parameter & SD & $\mathbf{2 . 5 \%}$ BC & $\mathbf{5 \% ~ B C}$ & $\mathbf{1 0 \%}$ BC & 20\% BC \\
\hline \hline Moisture & $6.52 \pm 0.18^{\mathrm{e}}$ & $7.79 \pm 0.12^{\mathrm{d}}$ & $9.76 \pm 0.09^{\mathrm{c}}$ & $11.21 \pm 0.21^{\mathrm{b}}$ & $13.23 \pm 0.22^{\mathrm{a}}$ \\
\hline Ash & $2.58 \pm 0.13^{\mathrm{d}}$ & $2.83 \pm 0.13^{\mathrm{c}}$ & $2.84 \pm 0.08^{\mathrm{c}}$ & $2.98 \pm 0.13^{\mathrm{b}}$ & $3.31 \pm 0.17^{\mathrm{a}}$ \\
\hline Crude fiber & $2.60 \pm 0.07^{\mathrm{d}}$ & $2.87 \pm 0.06^{\mathrm{c}}$ & $3.49 \pm 0.08^{\mathrm{b}}$ & $4.16 \pm 0.19^{\mathrm{a}}$ & $4.26 \pm 0.29^{\mathrm{a}}$ \\
\hline fat & $2.68 \pm 0.04^{\mathrm{e}}$ & $3.63 \pm 0.22^{\mathrm{d}}$ & $4.23 \pm 0.09^{\mathrm{c}}$ & $4.88 \pm 0.22^{\mathrm{b}}$ & $5.81 \pm 0.28^{\mathrm{a}}$ \\
\hline Crude protein & $16.95 \pm 0.05^{\mathrm{e}}$ & $19.21 \pm 0.22^{\mathrm{d}}$ & $21.23 \pm 0.25^{\mathrm{c}}$ & $23.45 \pm 0.65^{\mathrm{b}}$ & $25.17 \pm 0.17^{\mathrm{a}}$ \\
\hline CHO & $68.67 \pm 0.28^{\mathrm{a}}$ & $63.67 \pm 0.22^{\mathrm{b}}$ & $58.44 \pm 0.31^{\mathrm{c}}$ & $51.87 \pm 2.58^{\mathrm{d}}$ & $48.24 \pm 0.66^{\mathrm{e}}$ \\
\hline
\end{tabular}

Values are means of triplicate determinations \pm standard deviation. Means in the same row bearing different superscripts are significantly different $(p<0.05)$. SD $=$ standard diet, $\mathrm{BC}=$ Buchholzia coriacea, $\mathrm{CHO}=$ carbohydrate. 
(NR\%), apparent digestibility (AD) and true digestibility (TD) of the diabetic control group were lower $(p<0.05)$ compared with the positive control group while the feed intake (FI), fecal nitrogen (FN), nitrogen intake (NI), nitrogen retention (NR), net protein utilization (NPU) and biological value (BV) of the diabetic control group were higher $(p<0.05)$ compared with the positive control group. The protein intake (PI), FI, BMG. NI, NR, EUN and EFN of $2.5 \%$ and $5 \% \mathrm{BC}$ treated groups were higher $(p<0.05)$ when compared with the positive and diabetic control group. The FI, PI, BMG, NI, and NR of the $10 \%$ and $20 \%$ BC treated groups were lower $(p<$ $0.05)$ when compared with the diabetic control group. The $\mathrm{FN}$ and $\mathrm{UN}$ of the $\mathrm{BC}$ treated groups were higher $(p<0.05)$ when compared with the diabetic and positive control groups. The $5 \%, 10 \%$ and $20 \%$ BC caused significant $(p<0.05)$ concentration-dependent decrease in the AD, TD, NPU and NR\% of the treated groups when compared with the diabetic and positive control groups (Table 3).

\section{Effects of $B$. coriacea on Biochemical Parameters in Diabetic Rats}

The HbA1c, FBG, TC, TG and LDL-C of the diabetic control group were higher $(p<0.05)$ when compared with the positive control group, while the HDL-C of the diabetic control group was lower $(p<0.05)$ compared with the positive control. The $B C$ caused significant $(p$ $<0.05$ ) decrease in the HbA1c, FBG, TC, TG and LDL$\mathrm{C}$ in a concentration-dependent manner when compared with the diabetic control group. The HDL-C of BC treated groups were higher $(p<0.05)$ in a concentration-dependent manner when compared with the diabetic control group. The HbA1c, FBG, TC, TG, HDL-C and LDL-C of the $20 \% \mathrm{BC}$ treated group were comparable to the positive control group (Table 4).

\section{Histopathology}

The diabetic control group showed no observable pancreatic islet while the $B$. coriacea treatment caused concentration-dependent increase in the pancreatic islet cells area and density which were comparable to the positive control group (Figure 1).

\section{DISCUSSION}

The acetone $B$. coriacea seed elicited hypolipidemic and antidiabetic activities as well as reversed pancreatic damage and improved nutrient utilization in alloxan-induced diabetic rats. The hypolipidemic and antidiabetic activities of $B$. coriacea are suggested to be mediated by oleic acid and linoleic acid derivatives.

Table 3: Effect of $B$. coriacea on the Nutrient Utilization in Diabetic Rats

\begin{tabular}{|c|c|c|c|c|c|c|}
\hline parameters & Normal control & Diabetic control & $2.5 \% \mathrm{BC}$ & $5 \% \mathrm{BC}$ & $10 \% \mathrm{BC}$ & $20 \% \mathrm{BC}$ \\
\hline $\mathrm{FI}(\mathrm{g})$ & $282.38 \pm 38.77^{d}$ & $330.05 \pm 25.85^{b}$ & $372.50 \pm 11.02^{a}$ & $297.93 \pm 10.74^{\mathrm{cd}}$ & $233.50 \pm 7.42^{\mathrm{e}}$ & $188.32 \pm 13.04^{f}$ \\
\hline $\mathrm{PI}(\mathrm{g})$ & $47.84 \pm 6.57^{d}$ & $56.02 \pm 4.38^{c}$ & $72.18 \pm 2.24^{a}$ & $63.97 \pm 2.31^{b}$ & $54.04 \pm 1.72^{c}$ & $47.66 \pm 3.30^{d}$ \\
\hline $\mathrm{BMG}(\mathrm{g})$ & $87.57 \pm 10.40^{b c}$ & $80.23 \pm 2.79^{c}$ & $105.60 \pm 5.20^{\mathrm{a}}$ & $88.22 \pm 6.81^{b}$ & $57.72 \pm 4.52^{d}$ & $44.13 \pm 6.82^{\mathrm{e}}$ \\
\hline PER & $1.85 \pm 0.07^{\mathrm{a}}$ & $1.44 \pm 0.09^{b}$ & $1.46 \pm 0.03^{b}$ & $1.38 \pm 0.06^{b}$ & $1.08 \pm 0.08^{c}$ & $0.92 \pm 0.09^{d}$ \\
\hline FER & $0.31 \pm 0.01^{\mathrm{ab}}$ & $0.24 \pm 0.02^{c}$ & $0.28 \pm 0.01^{b}$ & $0.30 \pm 0.01^{b}$ & $0.25 \pm 0.02^{c}$ & $0.23 \pm 0.02^{c}$ \\
\hline $\mathrm{NI}(\mathrm{mg})$ & $1297.76 \pm 178.21^{d}$ & $1519.77 \pm 118.77^{c}$ & $1958.28 \pm 60.84^{a}$ & $1735.36 \pm 62.59^{b}$ & $1466.01 \pm 46.59^{c}$ & $1293.10 \pm 89.52^{d}$ \\
\hline $\mathrm{FN}(\mathrm{mg})$ & $108.22 \pm 24.85^{f}$ & $155.64 \pm 16.48^{\mathrm{e}}$ & $174.15 \pm 13.03^{d}$ & $218.02 \pm 13.19^{c}$ & $234.21 \pm 8.85^{b}$ & $264.28 \pm 13.81^{a}$ \\
\hline UN (mg) & $41.10 \pm 3.51^{\mathrm{e}}$ & $38.97 \pm 0.05^{\mathrm{e}}$ & $69.37 \pm 1.99^{a}$ & $61.47 \pm 0.73^{b}$ & $51.93 \pm 0.32^{c}$ & $45.81 \pm 2.81^{d}$ \\
\hline $\mathrm{EFN}(\mathrm{mg})$ & $39.19 \pm 4.37^{c}$ & $35.99 \pm 1.29^{d}$ & $51.48 \pm 2.32^{a}$ & $45.29 \pm 2.52^{b}$ & $34.90 \pm 2.02^{\mathrm{de}}$ & $30.69 \pm 3.05^{\mathrm{e}}$ \\
\hline EUN (mg) & $11.93 \pm 1.75^{c}$ & $10.45 \pm 0.52^{d}$ & $16.83 \pm 0.95^{a}$ & $14.37 \pm 1.01^{b}$ & $10.21 \pm 0.80^{d}$ & $8.51 \pm 1.22^{\mathrm{e}}$ \\
\hline NR & $1148.78 \pm 153.22^{d}$ & $1325.16 \pm 102.57^{c}$ & $1714.76 \pm 48.89^{a}$ & $1455.87 \pm 50.21^{b}$ & $1179.86 \pm 38.14^{d}$ & $984.01 \pm 80.71^{\mathrm{e}}$ \\
\hline NR\% & $88.56 \pm 0.40^{a}$ & $87.20 \pm 0.20^{b}$ & $87.57 \pm 0.33^{b}$ & $83.90 \pm 0.27^{c}$ & $80.48 \pm 0.17^{d}$ & $75.97 \pm 1.15^{\mathrm{e}}$ \\
\hline$A D \%$ & $91.77 \pm 0.76^{a}$ & $89.78 \pm 0.32^{c}$ & $91.12 \pm 0.41^{b}$ & $87.45 \pm 0.35^{d}$ & $84.70 \pm 0.18^{\mathrm{e}}$ & $79.53 \pm 0.98^{f}$ \\
\hline TD & $88.74 \pm 0.65^{a}$ & $87.43 \pm 0.28^{b}$ & $88.49 \pm 0.43^{a}$ & $84.84 \pm 0.39^{c}$ & $81.64 \pm 0.23^{d}$ & $77.16 \pm 0.97^{\mathrm{e}}$ \\
\hline BV & $95.30 \pm 0.46^{b c}$ & $96.31 \pm 0.34^{a}$ & $95.03 \pm 0.08^{\mathrm{bc}}$ & $95.01 \pm 0.47^{\mathrm{bc}}$ & $94.81 \pm 0.14^{\mathrm{bc}}$ & $94.56 \pm 0.28^{d}$ \\
\hline NPU & $84.56 \pm 0.37^{\mathrm{ab}}$ & $87.50 \pm .15^{\mathrm{a}}$ & $84.09 \pm 0.36^{b}$ & $80.61 \pm 0.35^{c}$ & $77.40 \pm 0.25^{d}$ & $76.28 \pm 7.75^{d}$ \\
\hline
\end{tabular}

Values are means \pm standard deviation. Means in the same row bearing different superscripts are significantly different $(\mathrm{p}<0.05)$. BC $=B$ Bchholzia coriacea, $\mathrm{FI}=$ feed intake, $\mathrm{PI}=$ protein intake, $\mathrm{BMG}=$ body mass gain, $\mathrm{PER}=$ protein efficiency ratio, $\mathrm{FER}=$ feed efficiency ratio, $\mathrm{NI}=$ nitrogen intake, $\mathrm{FN}=$ fecal nitrogen, $\mathrm{UN}=$ urinary nitrogen, $\mathrm{EFN}=$ endogenous fecal nitrogen, $\mathrm{EUN}=$ endogenous urinary nitrogen, $\mathrm{AD}=$ apparent digestibility, $\mathrm{TD}=$ true digestibility, $\mathrm{BV}=$ biological value, $\mathrm{NPU}=$ net protein utilization, $\mathrm{NR}=$ nitrogen retention, \%NR = percentage nitrogen retention. 
Table 4: Effects of $B$. coriacea on Biochemical Parameters in Diabetic Rats

\begin{tabular}{|c|c|c|c|c|c|c|}
\hline Parameter & Normal control & Diabetic control & $2.5 \% \mathrm{BC}$ & $5 \% \mathrm{BC}$ & $10 \% \mathrm{BC}$ & $20 \% \mathrm{BC}$ \\
\hline HbA1c (\%) & $4.05 \pm 0.10^{d}$ & $10.65 \pm 1.99^{\mathrm{a}}$ & $8.70 \pm 0.73^{b}$ & $7.43 \pm 1.59^{b}$ & $6.60 \pm 0.07^{c}$ & $5.80 \pm 0.54^{d}$ \\
\hline FBG $(\mathrm{mg} / \mathrm{dl})$ & $93.17 \pm 12.80^{d}$ & $212.50 \pm 35.86^{a}$ & $152.83 \pm 6.74^{b}$ & $138.67 \pm 3.72^{c}$ & $100.83 \pm 9.50^{d}$ & $90.50 \pm 11.91^{\mathrm{d}}$ \\
\hline $\mathrm{TC}(\mathrm{mg} / \mathrm{dl})$ & $165.39 \pm 14.18^{\mathrm{e}}$ & $251.28 \pm 13.47^{a}$ & $224.62 \pm 9.61^{b}$ & $219.23 \pm 8.16^{\mathrm{bc}}$ & $203.07 \pm 10.44^{d}$ & $168.59 \pm 13.63^{\mathrm{e}}$ \\
\hline $\mathrm{TG}(\mathrm{mg} / \mathrm{dl})$ & $117.82 \pm 6.70^{d}$ & $195.77 \pm 5.88^{a}$ & $172.08 \pm 4.78^{b}$ & $136.15 \pm 6.18^{c}$ & $121.54 \pm 20.15^{\mathrm{de}}$ & $100.70 \pm 9.10^{\mathrm{e}}$ \\
\hline LDL-C (mg/dl) & $86.44 \pm 11.99^{\mathrm{e}}$ & $184.69 \pm 14.24^{\mathrm{a}}$ & $155.89 \pm 13.38^{b}$ & $144.19 \pm 6.84^{c}$ & $126.85 \pm 13.96^{d}$ & $78.51 \pm 20.38^{\mathrm{e}}$ \\
\hline
\end{tabular}

Values are means \pm standard deviation. Means in the same row bearing different superscripts are significantly different $(\mathrm{p}<0.05)$. BC $=B u c h h o l z i a$ coriacea, $\mathrm{HbA1c}=$ glycosylated hemoglobin, FBG $=$ fasting blood glucose, $\mathrm{TC}=$ total cholesterol, TG = triglycerides, HDL = high density lipoprotein cholesterol, LDL-C = low density lipoprotein cholesterol.
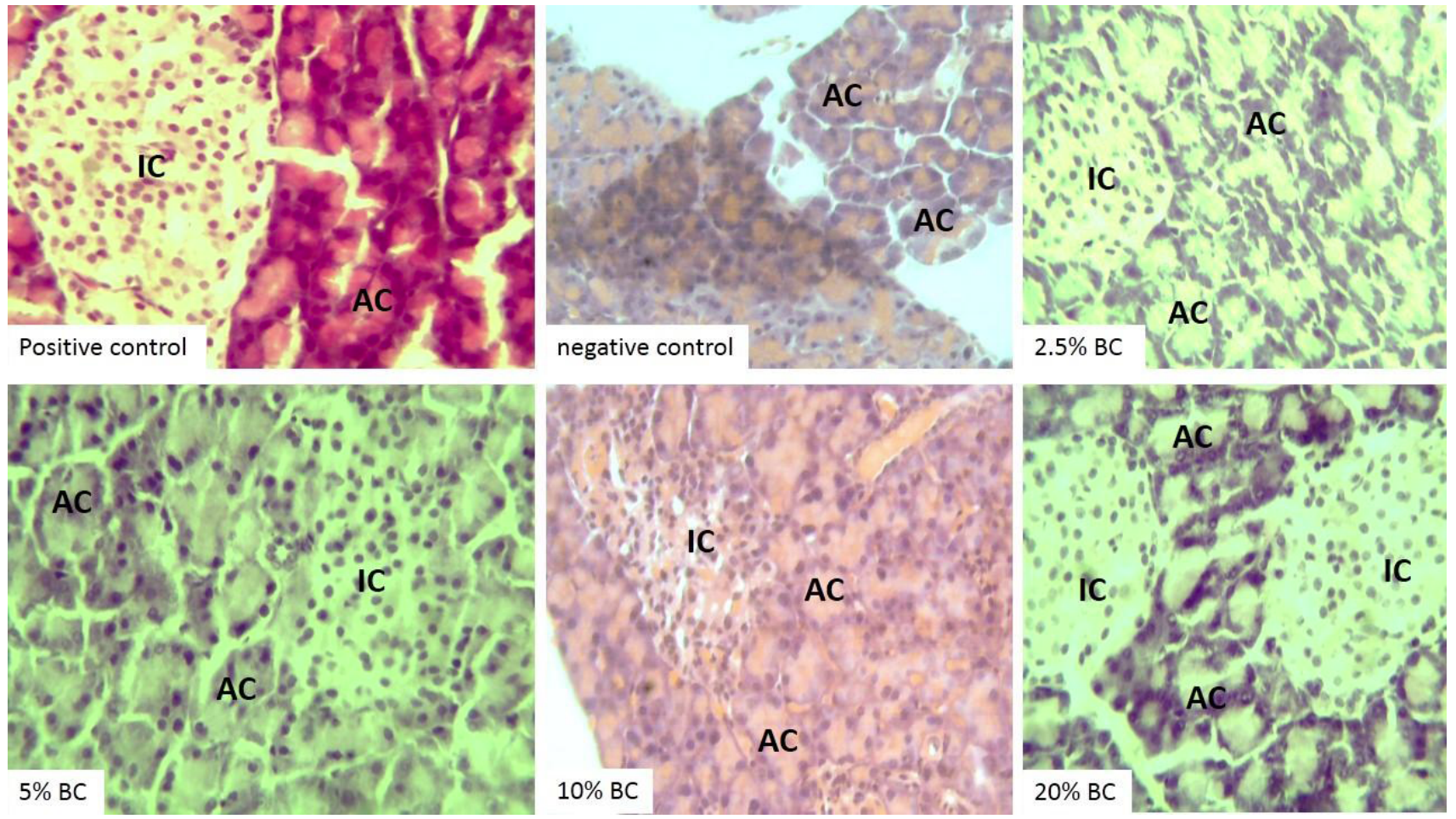

Figure 1: Photomicrograph sections $(H$ and $E \times 400)$ of pancreas of normal and diabetic rats.

Legend: $I C=$ islet cell, $A C=$ acini cell.

The GC-MS analysis showed the presence of mainly Oleic acid, hexadecanoic acids and the derivatives which were in agreement with the report of Duru et al. [17] on the chemical composition of Buchholzia coriacea seed. These compounds have been reported to possess anti-inflammatory, antioxidant and hypocholesterolemic activities [18]. Anti-inflammatory, antioxidant and hypocholesterolemic agents have been shown to promote healthy living in diabetic patients [19].

The supplementation of the ration with $B C$ increased the ash, crude fibre, fat, and crude protein content in a concentration dependent, which corroborates the report of Nnamani [20]. He noted that vegetables are cheap source of vitamins, mineral and amino acids. The increased crude fibre content may act as bulk laxative; which will reduce intestinal transit time, nutrient digestion and absorption [21].

The higher feed intake in the diabetic control is attributed to poor glucose uptake by cell as a result of insulin resistance or deficiency which characterize diabetes mellitus [22]. The decreased feed intake at $10 \%$ and $20 \%$ BC supplementation could be attributed to high fiber content which leads to satiation and satiety $[23,24]$ and/or poor palatability of the feed. The decrease in the BMG, FER and PER (Table 4) of the diabetic control group is due to muscle wasting which characterize alloxan induced diabetic condition [25]. 
The increase in BMG, FER and PER observed in $2.5 \%$ VA groups treated group may be attributed to the antidiabetic potential of BC [9].

The $\mathrm{BC}$ supplementation in the ration reduced the FBG, Hba1c, TC, TG, LDL-C and increase in HDL-C level in the treated rats when compared to the diabetic control group (Table 5). This could be attributed to increase in insulin secretion and/or sensitivity [26]. The $\mathrm{BC}$ caused concentration-dependent regeneration of the pancreatic islet cells damaged by alloxan administration (Figure 1). Pancreatic islet cell regeneration is associated with increased insulin secretion, enhanced glucose uptake, decreased serum glucose level and reduced glycosylation of hemoglobin [27]. The pancreatic islet cell regeneration may be linked to the antioxidant activity of BC [28]. The antioxidant retard the spontaneous production of free radical and cell membrane damage induced by alloxan in the treated rats [29].

The BC produced hypocholesterolaemic and hypotriglyceridemic effects in the alloxan-induced diabetic rats. Hypercholesterolemia and hypertriglyceridemia is the major risk factor for cardiovascular diseases; common complication of diabetes mellitus $[30,31]$. This indicates that BC could be employed in the treatment and/or prevention of complications of diabetes mellitus. The mechanism of the hypolipidemic effects of BC has not been elucidated but could be linked to enhanced insulin production and activation of lipoprotein lipase [32]. The hypolipidemic effects of BC supplemented ration corroborates with high dietary fiber content of the ration. Dietary fiber lower feed intake, reduce cholesterol and triglyceride absorption and elevate faecal bile acid and cholesterol excretion [33]. The hypolipidemic effects of B. coriacea is in agreement with the report of Olaiya and Omolekan [34] on the antihypercholesterolemic activity of ethanolic extract of Buchholzia coriacea in rats.

\section{CONCLUSION}

The extracts produced hypolipidemic and antidiabetic activities as well as reversed pancreatic islet cell damage in alloxan-induced diabetic rats. This study justifies the use of Buchholzia coriacea in the folkloric management of diabetic mellitus and suggests that its incorporation in excess of $5 \%$ in the diet should be avoided.

\section{DECLARATION OF INTEREST}

The authors declare no conflict of interest.

\section{AUTHOR CONTRIBUTIONS}

All the authors have accepted responsibility for the entire content of this submitted manuscript and approved submission.

\section{REFERENCE}

[1] Burkill HM. The useful plants of West Tropical Africa $\left(2^{\text {nd }} E d\right)$ Volume 5, Families S-Z, Addenal. United Kingdom; Royal Botanic Garden 2000.

[2] Nwaehujor CO, Ode OJ, Nwinyi FC, Udeh NE. Effect of methanol extract of Buchholzia coriacea fruits on streptozotocin-induced diabetic rats. J Pharmacol Toxicol 2012; 7: 181-91.

https://doi.org/10.3923/jpt.2012.181.191

[3] Enechi OC, Nwodo OF. Anti-ulcer and gastric anti-secretory activities of seed extract of Buchholzia coriacea in Wistar Albino rats. Afr J Biotechno 2014; 13(27): 2755-61. https://doi.org/10.5897/AJB2014.13858

[4] Ezeja MI, Ezeigbo II, Madubuike KG. Analgesic activity of the methanolic seed extract of Buchholzia coriacea. Res $J$ Pharmaceut Biol Chem Sci 2011; 2: 187-93.

[5] Okoye TC. Anti-diabetic Effects of Methanol Extract of the Seeds of Buchholzia coriacea and its Synergistic Effects with Metformin. Asian J Biomed Pharm 2012; 2(12): 32-6.

[6] Nweze NE, Asuzu IU. The Anthelmintic effects of Buchholzia coriacea seed. Nigerian Veterinary Journal 2006; 27(2): 6065

[7] Adisa RA, Choudhary MI, Olorunsogo OO. Hypoglycemic activity of Buchholzia coriacea (Capparaceae) seeds in streptozotocin-induced diabetic rats and mice. Exp Toxicol Pathol 2011; 63(7-8): 619-25.

https://doi.org/10.1016/j.etp.2010.05.002

[8] Olaleye SB, Ige AO, Michael OS, Owoyele BV. Analgesic and Anti-Inflammatory effects of Ethanol Extracts of Buchholzia coriacea Seeds in Male Rats. Afr J Biomed Res 2012; 15(3): 171-6.

[9] Obiudu IK, Okolie AC, Agbafor KN, Unaegbu ME, Engwa GA, Obiudu CV. Anti-diabetic property and phytochemical composition of aqueous and methanol extracts of Buchholzia coriacea seeds in alloxan-induced diabetic rats. J Med Sci 2015; 15(5): 241-5. https://doi.org/10.3923/jms.2015.241.245

[10] Amaechi NC, Ojimelukwe PC, Onoja SO. Effects of Vernonia amygdalina leaf on nutritional and biochemical parameters in alloxan-induced diabetic rats. J Nutr Ther 2018; 7(1) (in press). https://doi.org/10.6000/1929-5634.2018.07.01.2

[11] DHHS. Guide for the care and use of laboratory animals Institute of Laboratory Animal Resources Commission on Life Sciences, National Research Council. Washington, DC: National Academy Press, 1985.

[12] James CS. Analytical Chemistry of Foods. London; Blackie Academic and Professional 1995.

https://doi.org/10.1007/978-1-4615-2165-5

[13] Pellet PL, Young VR. Evaluation of protein quality in experimental animals In: Nutritional evaluation of protein foods ( $1^{\text {st }}$ Ed). Tokyo: The United Nations University 1980; pp. 41-57.

[14] Trivelli LA, Ranney PH, Lai HT. Glycohemoglobin in diabetic subjects. N Engl J Med 1971; 284: 353-7. https://doi.org/10.1056/NEJM197102182840703

[15] Friedwald WT, Leve IR, Fredrickson SD. Estimation of the concentration of low density lipoprotein seperation by three different methods. Clin Chem 1972; 18: 499-502.

[16] Berrougui $H$, Ettaib A, Gonzalez MDH, Sotomayor MA, Bennani-Kabchi N, Hmamouchi M. Hypolipidemic and 
hypocholesterolemic effect of argan oil (Argania spinosa L.) in Meriones shawi rats. J Ethnopharmacol 2003; 89: 15-8. https://doi.org/10.1016/S0378-8741(03)00176-4

[17] Duru M, Ugbogu A, Amadi B, Odika PO, Chima-Ezika O, Anudike J, Osuocha K. Chemical constituents of Buchholzia coriacea seed. Acadmia Edu 2013; 70: 39-41.

[18] Thijssen MA, Mensink RP. Small differences in the effects of stearic acid, oleic acid, and linoleic acid on the serum lipoprotein profile of humans. Am J Clin Nutr 2005; 82: 510-6. https://doi.org/10.1093/ajcn/82.3.510

[19] Shirwaikar A, Punitha ISR, Upadhye M, Dhiman A. Antidiabetic activity of alcohol root extract of Holostemma annulare in NIDDM rats. Pharm Biol 2007; 45: 440-5. https://doi.org/10.1080/13880200701388989

[20] Nnamani CV. (2013). Ethnobotanical survey of traditional leafy vegetables of Ikwo and Ezza clans of Ebonyi State, Nigeria. Nigerian Journal of Botany. Available at: http://nijbot.org/?p=135 (Accessed 12/01/2017).

[21] Howarth NC, Saltzman E, Robert SB. Dietary fiber and weight regulation. Nutr Rev 2014; 59: 129-39. https://doi.org/10.1111/j.1753-4887.2001.tb07001.x

[22] El-shobaki FA, El-Bahay AM, Esmail RSA. Effect of figs fruit (Ficus carica) and it's leaves on Hyperglycemia in alloxan diabetic rats. World J Dairy Food Sci 2010; 5: 47-57.

[23] Mišurcová L, Kráčmar S, Klejdus B, Vacek J. Nitrogen content, dietary fiber, and digestibility in algal food products. Czech J Food Sci 2010; 28: 27-35. https://doi.org/10.17221/111/2009-CJFS

[24] Lattimer JM, Haub MD. Effects of dietary fiber and its components on metabolic health. Nutrients 2010; 2: 1266-89. https://doi.org/10.3390/nu2121266

[25] Jain S, Bhatia G, Barik R, Kumar P, Jain A, Dixit VK. Antidiabetic activity of Paspalum scrobiculatum Linn. in alloxan induced diabetic rats. J Ethnopharmacol 2010; 127: 325-8.

https://doi.org/10.1016/j.jep.2009.10.038
[26] Kumar S, Kumar V, Prakash OM. Antidiabetic, hypolipidemic and antioxidant activities of Callistemon lanceolatus leaves extract. J Herbs Spices Med Plants 2011; 17: 144-53. https://doi.org/10.1080/10496475.2011.583139

[27] Ezeja MI, Anaga AO, Asuzu IU. Antidiabetic, antilipidemic, and antioxidant activities of Gouania longipetala methanol leaf extract in alloxan-induced diabetic rats. Pharm Biol 2015; 53: 605-14. https://doi.org/10.3109/13880209.2014.935864

[28] Nweze NE. Studies on the Antioxidant and Antimicrobial Activities of the Seed Extracts of Buchholzia coriacea (capparaceae). Nigerian Veterinary Journal 2011; 32(2): 1437.

[29] Bavarva JH, Narasimhacharya AVRL. Comparative antidiabetic, hypolipidemic, and antioxidant properties of Phyllanthus niruri in normal and diabetic rats. Pharm Biol 2007; 45: 569-74. https://doi.org/10.1080/13880200701499034

[30] Pfützner A, Weber MM, Forst T. Pioglitazone: update on an oral antidiabetic drug with antiatherosclerotic effects. Exp Opin Pharmacother 2007; 8: 1985-98.

https://doi.org/10.1517/14656566.8.12.1985

[31] Buchanan T, Buchanan T. Pancreatic $\beta$-cell loss and preservation in Type 2 diabetes. Clin Ther 2003; 23(Suppl): B32-B46. https://doi.org/10.1016/S0149-2918(03)80241-2

[32] Arulmozhi DK, Kurian R, Veeranjaneyulu A, Bodhankar SL. Antidiabetic and antihyperlipidemic effects of Myristica fragrans in animal models. Pharm Biol 2007; 45: 64-8. https://doi.org/10.1080/13880200601028339

[33] Van Bennekum AM, Nguyen DV, Schulthess G, Hauser H, Phillips MC. Mechanisms of cholesterol-lowering effects of dietary insoluble fibres: relationships with intestinal and hepatic cholesterol parameters. Br J Nutr 2005; 94: 331-7. https://doi.org/10.1079/BJN20051498

[34] Olaiya CO, Omolekan TO. Antihypercholesterolemic activity of ethanolic extract of Buchholzia coriacea in rats. Afr Health Sci 2013; 13(4): 1084-90. 